\title{
How Small Interest Groups Can Win the Outcome of Elections and Polls: Lessons for Countries with Modern and Developing Democracies
}

\author{
Nima S. Salami, Faculty \\ nimasalami@westcliff.edu
}

\begin{abstract}
It might sound perfectly obvious that in a real democracy, the majority's interests will always win against the interests of the minority. Unfortunately, in reality, this is not the case. Small interest groups can determine the outcome of elections and enact policies that favor their own interests, rather than those of the majority. This paper identifies how, contrary to the median-voter's model, small interest groups can win, if information asymmetries exist. Additionally, if gains and losses asymmetries are present and opportunity costs are involved for the voter, the same phenomena can occur. This article focuses on the role of interest groups in elections in democratic countries, explaining how they can enact policies that are against the public's will.
\end{abstract}




\section{Introduction}

Many believe that in a real democracy, people would vote for what their needs and wants are, and the majority would win the outcome. The median-voter model explains that since legislators want to stay in office, they would be more likely to maximize their probabilities and enhance their chances of remaining in office (Congleton, 2004). For that reason, they will follow the wills of what the majority of people are asking for, so they can win the next round over the opposing party. However, in reality, this is not what is happening as small interest groups can win against the majority (Appleyard \& Field, 2014).

International trade, trade policies, and free trade have always been a matter of debate among the supporters and the opponents (Hill \& Hult, 2018). For instance, supporters explain that the overall outcome of trade liberalization policies and free trade have been proven to be for the benefit of society as a whole; whereas, the opponents argue that the free trade policies have caused manufacturing jobs to leave the developed countries and land in less advanced economies instead (Hill \& Hult, 2018).

The opponents of free trade believe that liberalization of trade is detrimental for the local industries and workers' wages, and therefore it shall be restricted or even stopped (Bartlett \& Steele, 1996). On the other hand, supporters of free trade agreements believe that as a whole, benefits of trade liberalization outweighs the costs (Krugman, 1996). Although more detailed research has shown that the free trade argument is most probably the correct one, the debates are still going on. Each side wants to have their own country's trade policies and governmental legislation support their views on international trade (Appleyard \& Field, 2014).

Since in democratic countries voting has been the basis for defining many national and international law and determining major decisions, people might think that each party would need to work hard to appeal to the majority's opinion in order to sway the vote in their favor (Grossman \& Helpman, 2002). Under specific circumstances small interest groups can win against the majority's will, resulting in policies that do not support the majority's benefits nor are consistent with national welfare
(Appleyard \& Field, 2014; Grossman \& Helpman, 2002). This paper will explain why and how this phenomenon happen and discusses possible ways of hindering it from continuing.

\section{Discussion}

When president Trump was elected as the $45^{\text {th }}$ president of the United States, he immediately promised to follow-thorough on his protectionist agenda regarding international trade announced during his presidential campaign (Abdulkareem, 2018). Although president Trump did not win the majority of popular votes over his democrat rival Hillary $R$. Clinton, he had enough electoral votes to take the election (Barthélémy, Martin \& Piggins, 2019). Thus, although the majority of the people in the US, did not support the policies vocalized by Trump, they were going to be enacted regardless.

In this example, it has been argued that electoral systems were the reason behind the minority candidate's success over the majority. However, this is not an isolated example. In the past other small interest groups have determined the outcomes of the democratic political system in the United States. For instance, when tariffs are put on certain industries, products, and countries, only a small group of people stood to benefit, and yet interestingly the majority of people would accept the outcome (Appleyard \& Field, 2014). To explain why this is happening Appleyard and Field (2014) have suggested that there are two conditions required to produce such contradictory results in a society.

First Condition: When There are Informationgathering and Opportunity Costs Involved with the Voting

Appleyard and Filed (2014) suggest that when there are information gathering and opportunity costs involved with the voting, potential eligible voters might not participate. The reason for this is that since the voters might see the process of information gathering to vote as costly, and would expect small gains for their participation, they may not go to the poll (Appleyard \& Field, 2014). Consequently, since the opportunity costs for voting seem to be high, 
and the voter would calculate the expected net benefit as negative, he/she may not participate.

Second Condition: The Voter Assumes One Vote Will Not Swing the Results

When the voter assumes one vote will not swing the results, he/she would most probably not participate in the voting, due to the belief that his/her vote would not change anything. Therefore, the voter would accept the results, without any direct participation in the voting processes (Appleyard \& Field, 2014). This has been termed, the free-rider effect, where individuals accept the results of a vote without spending any time, cost, or effort (Peters, 1998).

The reason that the free-rider effect would be problematic for a democracy since individuals have different incentives based on their asymmetric loss and benefit analysis. It is most rationale to believe that the number of individuals who would participate in voting for personal gain, are larger than those who are participating for the public good (Appleyard \& Field, 2014; Peters, 1998). If a voter is going to the poll to vote on a trade policy that supports their own local business, he/she has a greater incentive to vote. On the contrary, someone who would theoretically vote against a trade policy for the collective good, is possibly less incentivized to do so, since the impact of the policy is less visible on his/her life (Appleyard \& Field, 2014; Peters, 1998). Therefore, under this condition, democracy would be less effective in supporting the will of the majority and the smaller groups who have a larger incentive to make an effort could win.

\section{How Small Interest Groups Can Influence Political Outcomes}

According to Sulock (1990) the free-rider problem will arise when an individual feels that he/she can benefit from a policy without bearing any of the costs. For instance, Sulock (1990) brings up the classic example of a lighthouse, as a public good, where its signal is nonrival and nonexclusive, meaning that all sailors can benefit from the lighthouse's signal and no one could be excluded or denied (Sulock, 1990). He further explains that the nonrivalry and nonexclusive properties of the public good makes the free- rider effect a problem. The problem is that it would affect companies that are making and selling public goods, since they cannot receive enough voluntary contributions from beneficiaries to cover their costs (Sulock, 1990).

Appleyard and Field (2014) have suggested that the same cost and benefit analysis for the small interest groups regarding a policy that is supporting their industries/opinions/views would suggest that a greater benefit for them is expected comparing to what the public majority group has. These greater benefits would more than likely enable small interest groups to overcome their in-group free-rider effect. Therefore, their solidarity, participation, and vote for their candidate would create a small voter turnout to help the solid minority group win (Appleyard \& Field, 2014). For instance, as Appleyard and Field (2014) explain, "the same phenomenon can lead to a status quo bias against liberalizing trade policy through lower levels of protection even though doing so carries the promise of improving aggregate welfare" ( $p$. 370).

Additionally, it has been shown that interest or pressure groups can be even more successful in elections and polls if they are "large enough to be visible, but small enough to control the free riding of their members" (Vousden, 1990, p. 198). In this case, these smaller interest groups become more effective and efficient than larger indifferent groups as they have a commonality of interest, per capita organization, and relatively low information gathering costs (Vousden, 1990).

Also, these small interest groups are more likely to fund their supported political campaigns. That would lead to providing better candidate visibility and low-cost interest-groupcentered information for the small interest group voters to motivate them to overcome the free-rider effect (Appleyard \& Field, 2014). Moreover, their campaign funding contributions could attract a candidate's attention in terms of considering supporting the funding groups' views in the future, a rent seeking activity, as the small interest group would bear some costs that could be used for future benefits from a policy (Appleyard \& Field, 2014). For instance, the results of such activities have been many protectionist trade policies, such as tariffs and 
quotas, that have been enacted by politicians to support a small group's interests rather than supporting the public's welfare (Abboushi, 2010; Hill \& Hult, 2018). Under such conditions, owners of certain industries would support candidates that had pro-protectionist trade laws (Abboushi, 2010), and the owners would, in turn, fund their political campaigns to win (Applyard \& Field, 2014).

It is worthy to note that such interest groups' investments in funding political campaigns are always less than the expected returns from that policy (Appleyard \& Filed, 2014). Therefore, if a party is spending millions of dollars to fund a certain political campaign, an individual may safely assume that the returns are supposed to be greater than what has been spent in support of the campaign. Moreover, the rent seeking activities of such small interest groups can even expand beyond the funding of political campaigns to engagement in corruptive activities such as briberies (Appleyard \& Field, 2014). These practices are called "directly unproductive activities," since the funds that are being used by these small interest groups are meant to influence the politicians and rearrange the distribution of income, not to create wealth for a society as a whole (Appleyard \& Field, 2014). The rent seeking activities of these small interest and pressure groups could go even farther by supporting other pressure groups in the hope of later reciprocities (Appleyard \& Field, 2014). In this scenario, for instance, the combined support of several trade protectionist groups would finally create enough political critical mass to enable a protectionist candidate to win an election over the majority's trade liberalizing candidate, which would in return, put restrictive trade laws in place. This phenomenon has been referred to as "logrolling" of status quo bias, where small interest and pressure group/s stand to benefit from the policies in expense of the loss of the greater majority group, which would be suffering from the free-rider effect (Appleyard \& Field, 2014).

The aforementioned issues are not limited to developing countries with new democracies. Even countries with modern democracies and more experience are facing losses of elections to minority pressure groups (Hashmi, 2018).
Therefore, solutions for the matter need to be sought and researched.

\section{Conclusions}

People might think that with a democracy, the will of majority would rule the society. Although the definition might sound about right, there are conditions under which small groups can win the outcome of an election as opposed to the majority, resulting in unfavorable rules and regulations that could potentially harm the majority and benefit the minority (Appleyard \& Field, 2014). Since such outcomes could most likely be detrimental for the welfare of a nation as a whole, the forces that are able to create such conditions should be identified, analyzed, and remedied to safeguard the elections.

A possible solution for the problem could be to inform people about the phenomenon and make them aware that any individual's participation in an election does matter. This must be reinforced as even though the public opinion or the predictions imply the success of the majority's party over the minority, this is not always the case. In order to do so, the majority party's members should stay away from explanations reliant upon clichés and clearly explain to the public why an incentivized minority, a pressure group, would be able to win an election. Explaining historic instances and the amount of losses that a society has seen previously under similar situations, documenting the losses during such periods and publishing them before the upcoming elections could be among the suggestions considered.

It has been shown that all countries, with both young and developing democracies, as well as old and developed ones, are likely to suffer from rules and regulations that are passed by the minority who have won the elections (Hashmi, 2018). For instance, it has been shown that free trade agreements are for the profit of all nations, protectionist laws in the US are enacted to further restrict free trade in favor of only some industries and at a loss to the public (Abboushi, 2010).

More studies are required to analyze the same issue for different democratic models cross the world, to measure the susceptibility of each country to such possible unfavorable outcomes. Additionally, research must be done to observe 
how each political model has considered the issue, including their defensive mechanisms. The findings can be shared with scholars for further analysis, and for possible effective suggestions for how to remedy this situation. 


\section{REFERENCES}

Abboushi, S. (2010). Trade protectionism: Reasons and outcomes. Competitiveness Review, 20(5), $384-394$. http://dx.doi.org/10.1108/10595421011080760

Abdulkareem, Y. A. (2018). Conflict, international trade and president Trump's isolationist policies. Journal of International Trade Law \& Policy, 17(1), 34-45. http://dx.doi.org/10.1108/JITLP-07-2017-0024

Appleyard, D. R., \& Field, A. J. (2014). International economics (8 ${ }^{\text {th }}$ ed.). New York, NY: McGrawHill/Irwin.

Barthélémy, F., Martin, M., \& Piggins, A. (2019). The 2016 election: Like 1888 but not 1876 or 2000. PS, Political Science \& Politics, 52(1), 20-24. http://dx.doi.org/10.1017/S1049096518001269

Bartlett, D. L. \& Steele, J. B. (1996). America: Who stole the dream? Kansas City: Andrews and McMeel

Congleton, R. D. (2004). The median voter model. In The Encyclopedia of Public Choice (pp. 707-712). Boston, MA: Springer.

Grossman, G. M., \& Helpman, E. (2002). Interest groups and trade policy. Grafton, WI: Princeton University Press.

Hashmi, R. S. (2018). Modern democracy: Issues in theory and practice. Journal of Political Studies, 25(1), 17-32. Retrieved from https://search.proquest.com/docview/2067961435?accountid=158986

Hill, C. W. L., \& Hult, G. T. M. (2018). International business: Competing in the global marketplace (12 ${ }^{\text {th }}$ ed.). New York, NY: McGraw-Hill Education.

Krugman, P. (1996). Pop intemationalism. MIT Press, Cambridge (Ma.)-London, 1, 998.

Milanovic, B., \& Squire, L. (2005). Does tariff liberalization increase wage inequality?-Some empirical evidence. The World Bank.

Peters, E. (1998). The rational voter paradox revisited. Public Choice (1986-1998), 97(1-2), 179. Retrieved from https://search.proquest.com/docview/194650539?accountid=158986

Sulock, J. M. (1990). The free rider and voting paradox "games". Journal of Economic Education (19861998), 21(1), 65. Retrieved from https://search.proquest.com/docview/216538830?accountid=158986

Vousden, N. (1990). The economics of trade protection. UK: Cambridge University Press. 